\title{
AT-TAFRTER
}

VOLUME 14 NOMOR 1 TAHUN 2021

10.32505/at.vl4i2.3940

\section{EFL Student Difficulties of Online Learning During Coronavirus Pandemic at IAIN Langsa}

\author{
Muslem \\ Dosen FTIK IAIN Langsa \\ muslemabubakar@iainlangsa.ac.id
}

\begin{abstract}
This research was aimed to find out the EFL students' difficulties and psychological impact of online learning during coronavirus (COVID-19) at IAIN Langsa. This research used a qualitative approach. Documentation and interview were used to collect the data in this research. The subject of this research was EFL students of the English education department at the sixthsemester students of IAIN Langsa. The result of this research showed that the students encountered several difficulties in learning online consisting of; Internet data, internet connection, difficulties in doing assignments, intrusion, lack of experience in using technology, comprehending the lesson of EFL and interaction between students and lecturer. On the other hand, the psychological impact of online learning encountered by the students such as; frustration and feeling sadness.
\end{abstract}

Keywords: Coronavirus (Covid-19), Learning Difficulties, Online Learning, Pandemic

Abstrak: Penelitian ini bertujuan untuk mengetahui kesulitan siswa EFL dan dampak psikologis dari pembelajaran online selama Coronavirus (COVID-19) di IAIN Langsa. Penelitian ini menggunakan pendekatan kualitatif. Dokumentasi dan wawancara digunakan untuk mengumpulkan data dalam penelitian ini. Subjek penelitian ini adalah mahasiswa EFL dari Program Studi Tadris bahasa Inggris semester VI IAIN Langsa. Hasil penelitian ini menunjukkan bahwa para siswa mengalami beberapa kesulitan dalam belajar online terdiri dari; Data internet, koneksi internet, kesulitan dalam melakukan tugas, intrusi, kurangnya pengalaman dalam menggunakan teknologi, memahami pelajaran dari EFL dan interaksi antara siswa dan dosen. Disisi lain, dampak psikologis dari pembelajaran online yang dihadapi oleh mahasiswa seperti frustasi dan merasa sedih.

Kata kunci: Coronavirus (Covid-19), Kesulitan Belajar, Pembelajaran Online, Pandemi 


\section{INTRODUCTION}

EFL students are English Language Learners who are not native English language to apply it in the non-English speaking country. Harmer (2007) explains that EFL described situations where students were learning English to use it with any other English speakers in the world - when the students might be tourists or business people. EFL is still limited in using the English language, they use the language particularly in the learning environment, but it is possible, for them to implement it in daily life to increase their English skill. Brown (2001) says those foreign language contexts are those in which students do not have ready-made contexts for communication beyond their classroom.

EFL students are prepared to possess English language skills although in a non-English speaking country. The English Language is international communication in the world so that the EFL students are part of a global targetlanguage community. They are educated in mastering English as a Global Language which has a powerful influence to participate internationally for the progress of the nation. Thus the English language is necessary to learn. In this 4.0 era and the COVID19 pandemic phenomena, the use of technology is increasing rapidly. To require the knowledge, the English language is completely essential to get more references and sources. Additionally, the opportunity to study online abroad or join in an international webinar to create a progression in Indonesian youth.

Coronavirus disease or well-known as COVID-19 originally come from the Chinese, Hubei Province. This virus has spread all over the world which impact of this phenomenon influences the Education institution in many countries concluding Indonesia. The World Health Organisation has declared COVID-19 as a Pandemic which has been increasing internationally. The first case of Covid-19 in Indonesia was confirmed on March 2, 2020. Consequently, all teachinglearning activities in the education institution have to be stopped immediately (Setiawan, 2020). To restrain the spreading of this virus conducting social distancing to reduce the impact of this virus on human health especially for students, social distancing is a conscious increment in the physical gap between people to curb the dissemination of disease. Due to social distancing, the changes of the academic system to online learning is necessary to implement. According to Moorhouse (2020), the global spread of the COVID-19 pandemic causes class suspensions resulting in the need for online learning.

Applying online learning during the pandemic is suitable for learners, they can learn from home, without going to school, so that this ease students to receive the knowledge. Moreover, the time is set freely by the agreement of the lecturer and students as a result the process of teaching-learning is delivered well without breaking the social and physical distancing regulation. According to Means et. Al (2010), the use of online learning is indeed practical because it can be used 
anywhere and anytime. However, to implement online learning predictably becomes complicated, so that the lecturer and the teacher have to prepare the second plan if one of the online learning platforms or methods is not capable to run successfully. Therefore, do not close your eyes that the implementation of online learning raises its problems (Smart \& Cappel, 2006). The difficulties of learning online may become worst when the EFL students face it, due to learning a foreign language is complicated during coronavirus pandemic especially the higher education students. EFL describes a situation where students were learning English to use it with any other English speakers in the world.

In addition, the previous study had conducted by Akhter (2020) who is Assistant Professor, Department of English, College of Sciences and Languages Sajjir, Shaqra University, Kingdom of Saudi Arabia, with the title is "Problems and Challenges Faced by EFL Students of Saudi Arabia during COVID-19 Pandemic. This study aims to find out the problems and challenges faced by EFL students because of the limited resources. This study used a qualitative approach. This study found some of the common difficulties that every student faces are mentioned as follow: 1) Lack of experience in using technology: Some students when facing online learning are hesitant to adapt themselves because they have less tech experience; 2) Lack of motivation, the students lose their inspiration, it is one of the influential obstacles is faced by the students. Moreover, this triggers a loss of encouragement to learn; 3) Personal Cognitions: some students also felt like they do not have the expertise or abilities to participate. Technical Issues, many students do not have the high quality of internet connection to require online learning, also many of them do not possess devices and technological support.

This research aims to investigate the students' difficulties and the psychological impact of online learning During the Coronavirus (COVID-19) Pandemic at the English education department of IAIN Langsa. The barriers that are encouraged by the students obstruct the online teaching-learning process. Additionally, this research is expected to enhance the students' knowledge about EFL students' difficulties in online learning, during the coronavirus (covid-19) pandemic so that they can reduce the difficulties in their online learning. Moreover, this research can be expected as a reference to find out the online learning difficulties that were faced by EFL students, As a result, they can understand the difficulties of this pandemic for online teaching and learning especially for the EFL.

\section{Online Learning}

The term online learning (or, as it is sometimes called, distance learning) includes some computer-assisted instruction methods. Online learning can be described as learning via the internet which brings educational content, resources 
and supports the students, allowing meaningful interaction and facilitating the creation of knowledge. Almarabeh (2014) defines online instruction as an innovative approach to delivering instruction to a remote audience, using the Web as the medium. Online learning, refers to instructional environments supported by the internet. Online learning comprises a wide variety of programs that use the internet within and beyond school walls to provide access to instructional materials as well as facilitate interaction among teachers and students (Bakia, 2012).

\section{Types of Online Learning}

According to Fordham University (2021), Online learning is a comprehensive term that includes many instructional environments and approaches. Consists of:

\section{a. Asynchronous Online learning}

Asynchronous online learning does not offer to study in real-time. content and assignments are given a time frame to complete course work and exams for the students. According to Stefan Hrastinski asynchronous Online learning is the process of transferring knowledge online to support work relations among learners and teachers, even when participants can not be online at the same time. The interaction in the teaching-learning process frequently takes place by using media such as; discussion groups, blogs, email, and wikis. The knowledge can transfer without meeting class because Asynchronous learning is unlimited of time and place. As a result, there is no class time meeting the application of asynchronous learning. Many applications can be used to support the learning, such as youtube, TikTok, WhatsApp, telegram, google form, Facebook, Instagram and other applications that are capable to share the teaching material. Students who have time constraints or busy schedules are compatible with the Asynchronous online learning environment.

The asynchronous is useful in online learning during the coronavirus pandemic because the teaching-learning process can conduct anytime and anywhere, without the limitation of time. The most convenient is that each student and teacher has an opportunity to work at their own pace and preferred times. In other words, the participants in the class are not present at the same time and place but still together by chance and plan in online learning. This type of online learning facilitates the learner to log on to an e-learning environment at any time to download documents or send messages to teachers and peers (Hrastinski, 2008). 


\section{b. Synchronous Online Learning}

Synchronous online learning is offered to study in real-time. this online type of learning provides the teacher/lecturer and students to interact online communicatively and simultaneously. The teaching-learning process takes place in a virtual classroom directly at the same time. The tools for synchronous learning consist of; Text-based tools, live audio, and video tools, content, display and other interactive tools, ways to deliver the live online learning through a webinar, participants interact through text, video, or audio chat. Many applications can be used like, zoom, Webex, WhatsApp, Line, google meet, and so on. Synchronous learning environments allow the students to participate in the learning environment from a distance in real-time.

During the corona virus pandemic, many teachers applicate this type of online learning, besides easing the teacher to deliver their teaching also enhance unique skills in live online, particularly in learning native and second languages such as; listening and reading comprehension, storytelling skills, fluency including proper pronunciation, well-articulated, well-spoken oral argument, debate, presentation skills, role-play simulated situations in preparation for realworld scenarios, well-reasoned conversation on disciplined on discipline-specific topic, and other common skills (Finkelstein, 2006). These skills reduce the barriers that are faced by the EFL students and teachers in this online learning situation during the pandemic.

\section{c. Blended Learning}

Blended Learning is a learning environment that allows for both in-person and online interaction. Generally, blended learning is provided face-to-face sessions for computer-based communication in between several times during a semester. According to Staker and Horn, as cited by Kseniya Volchenkova (2016), blended learning is a formal education program in which students learn at least in part through online delivery of content and interaction with some element of students control over time, place, path, and pace at least in part at a supervised brick-and-mortar location away from home. She also defines that blended learning as a method of teaching which combines the most effective face to face teaching, techniques, and online interactive collaboration, both constituting a system that functions in constant correlations and forms a single whole.

\section{d. Providing Continuity}

During the pandemic, crisis impacting all or part of campus, to reduce it keeping in touch with students is vital because of any changes of class(es). The instructors should share information with the students about changes in schedules, assignments, procedures, and broader course expectations. The way to ease students' anxiety and save them from difficulties in learning is early and 
frequent communication which is necessary to conduct. Interruptions in the teaching-learning process can develop for many reasons. During an interruption of their learning, students may encourage complicated and anxious experiences. It is the best strategy to organize teaching design in place to keep students informed and engage about how the class will proceed.

\section{e. Distributing Materials}

The Teacher or lecturer should have the capability to prepare and renovate a syllabus that modifies the design of learning activities, assignments, tasks, content, outstanding dates, In the event of an interruption. establishing clear communication procedures and pathways is the important thing for the instructors to deliver updated learning materials. The teacher must consider when post-learning material, the students can be confirmed that they find it. To illustrate, the simple way to distribute the new material is to email the students as connections to online resources, such as; websites, videos, podcasts, and so on.

\section{f. Creating and contributing Content}

The online educator is proficient when they can create their learning material content, which facilitates them to suit their lesson plan and teaching in the virtual class. Effective methods to provide continuity are emailing documents and hosting discussion forums. However, sharing content is allowed to ease them deliver their teaching, to avoid time-consuming. A variety of multimedia resources are applicable for online learning. Fortunately, educators should not be obligate to create most of the learning materials for the students. Sometimes unpredictable interruptions come, some of them have no time to master content creation tools and then create, edit and post content.

\section{g. Develop Collaborative Learning}

By fostering collaboration teaching-learning process is capable to execute well. According to Smith \& Gregor (1998), collaborative learning is involving a joint intellectual effort by students and teachers together, commonly students are working in groups of two or more, to look for a mutual understanding solution, meaning, or creating a product, it represents an umbrella term for many educational approaches. Thus online learning process is based on students' discussion and activity with the learning material. It is necessary to ensure the online learning is not distracted by interruptions So that implementation of collaborations or prevent the development of student-centred instruction is capable to deliver well. 


\section{RESEARCH METHOD}

The research design of this study is qualitative research and it was conducted at the English education department of the Faculty of Tarbiyah and Teachers' Training of IAIN Langsa in April 2021. The research focused on the online learning difficulties encountered by EFL students of IAIN Langsa during the Coronavirus (COVID-19) Pandemic and the psychological impact of the online learning difficulties encountered by EFL students of IAIN Langsa during the Coronavirus (COVID-19) Pandemic.

Carrie William as cited in Creswell (2003) defines that Qualitative research is also described as an unfolding model that occurs in a natural setting that enables the researcher to develop a detail from high involvement in the experience. The subject of the research is the students of the English department of IAIN Langsa, the academic year 2020/2021. The students consist of the second semester to the eighth semester. The researcher only took the sixth-semester students consisting of 3 to 10 students and the data were collected randomly.

The data collection technique is the most strategic step in the research because the main goal of this research is to obtain the data. To collect the data accurately, the researcher used written interviews, and documentation as the instrument to assist in collecting the data. The researcher collected documents on online learning. According to Cresswel (2003), documentation is a valuable source of information in qualitative research. This documentation technique is completely suitable to be used to conduct a study of the difficulties in the learning process. The result of documentation in the form of zoom meetings, online learning pages, assignments, and so forth. Documentation was done to gain the data of an event to answer the research questions which the researcher gets the documentations from the lecturers and students.

To collect the information in-depth, the researcher conducted interviews. The Interview involves asking questions and receiving answers from respondents (Marsvasti, 2004). The Interview is a method of collecting data that is used to obtain information directly from a source (Sudaryono, 2017). Based on the explanation above, the interview is a process of exchanging information between two people or more. Thus, by applying the interview, the researcher was capable of investigating EFL students difficulties in online learning accurately. The researcher used a structured interview to obtain the data, the interview was conducted via online Google form by using written interview.

In this research, the researcher used descriptive qualitative as a technique of data analysis. Descriptive qualitative analysis is a technique that aims to describe and interpret the meaning of data that have been gathered. To find out the data accuracy. There are three steps in analysing data qualitatively, such as reducing data, data display, or presenting and conclusion or verification; 
1. Reducing data is a process of classifying, organizing, and selecting the data. It means that the researcher chooses the information which the suitable and unsuitable data based on the problem of research.

2. Data display or presenting the information that obtained before can be presented. It is based on reality about good EFL Lecturers.

3. Conclusion data or verification, the researchers must be able to make a summary of the finding. The researcher can find a new theory during concluding of the finding.

\section{RESULTS AND DISCUSSIONS}

In this research, the researcher analysed the data gathered from conducting the research. The researcher gained the data by conducting written interviews to find the result in depth. Additionally, the researcher got documentation to gain accurate data for answering the research questions which consisted of; What are the online learning difficulties encountered by EFL students of IAIN Langsa during Corona Virus (COVID-19) Pandemic? And What is the psychological impact of online learning encountered by EFL students of IAIN Langsa during the Coronavirus (COVID-19) Pandemic?. The result and the discussion are following:

\section{Results of Interview}

\begin{tabular}{|c|l|l|}
\hline NO & \multicolumn{1}{|c|}{ QUESTIONS } & \multicolumn{1}{c|}{ ANSWERS } \\
\hline 1. & $\begin{array}{l}\text { How is the process of } \\
\text { online learning during } \\
\text { the coronavirus } \\
\text { pandemic based on your } \\
\text { opinion? }\end{array}$ & $\begin{array}{l}\text { Most of the students' opinions about online } \\
\text { learning during the coronavirus pandemic are } \\
\text { not effective, the online learning process does } \\
\text { not demonstrate the best outcome. In } \\
\text { addition, the method of teaching, the student } \\
\text { can not feel it real. They often get bored, then } \\
\text { ignore the learning. Additionally, using } \\
\text { applications such as zoom makes the } \\
\text { students find more challenges. As EFL } \\
\text { students, they experience misunderstandings } \\
\text { in learning the language. Thus it is not } \\
\text { maximal than offline learning. } \\
\text { some of them argue that it is more valuable } \\
\text { conducting online learning than do not learn } \\
\text { anything during a coronavirus pandemic and } \\
\text { the schedule is arrangeable, as a result, they } \\
\text { can learn well }\end{array}$ \\
\hline
\end{tabular}




\begin{tabular}{|c|c|c|}
\hline $\mathrm{NO}$ & QUESTIONS & ANSWERS \\
\hline & $\begin{array}{l}\text { Have you faced online } \\
\text { learning difficulties } \\
\text { during the coronavirus } \\
\text { pandemic? }\end{array}$ & $\begin{array}{l}\text { Some of them often experience the } \\
\text { difficulties of learning online in many EFL } \\
\text { subjects, especially in learning a new subject, } \\
\text { moreover, they must solve the problem and } \\
\text { do the task of the subject. They often } \\
\text { encounter difficulties in understanding the } \\
\text { material. Finally, they face obstacles from the } \\
\text { signal and so forth. }\end{array}$ \\
\hline 3 & $\begin{array}{l}\text { What are the difficulties } \\
\text { that you face when } \\
\text { learning online during } \\
\text { the coronavirus } \\
\text { pandemic? }\end{array}$ & $\begin{array}{l}\text { Most of them encounter the same } \\
\text { difficulties, such as; the internet connection } \\
\text { in every remote village is not stable, they feel } \\
\text { hard to enjoy the teaching-learning process, } \\
\text { the challenges are faced to understand the } \\
\text { material of learning, as a result, they face } \\
\text { difficulties in applying the knowledge } \\
\text { directly in real life, piling up tasks and close } \\
\text { deadlines, limited quota, online distraction, } \\
\text { they face boredom via online learning } \\
\text { application such as; zoom, the students } \\
\text { become passive in the class because difficult } \\
\text { to participate actively, lastly, the students } \\
\text { do not focus to stay at the zoom meeting } \\
\text { cause the feel is not like study. The lecturer } \\
\text { explains but this is different. }\end{array}$ \\
\hline 4 & $\begin{array}{l}\text { When did you face the } \\
\text { difficulties of online } \\
\text { learning? }\end{array}$ & $\begin{array}{l}\text { The students frequently face the difficulties } \\
\text { of online learning, when the weather } \\
\text { suddenly becomes cloudy and the signal } \\
\text { disappears instantly and the quota package } \\
\text { runs out. When the lecturer explains, the } \\
\text { students feel unmotivated to listen and learn } \\
\text { the material, as a result, the students are } \\
\text { incapable to understand the learning } \\
\text { material fully. Then, when the lecturer asks } \\
\text { the students to answer or explain } \\
\text { something. The internet connection is not } \\
\text { always good. So maybe the explanation is } \\
\text { unclear. The students' voice shows up late, } \\
\text { then the video. }\end{array}$ \\
\hline 5 & How many times did you & Most of them encounter the difficulties of \\
\hline
\end{tabular}




\begin{tabular}{|c|c|c|}
\hline $\mathrm{NO}$ & QUESTIONS & ANSWERS \\
\hline & $\begin{array}{l}\text { face the difficulties of } \\
\text { online learning? }\end{array}$ & $\begin{array}{l}\text { online learning, almost every meeting and } \\
\text { they said that sometimes it is really hard to } \\
\text { deal with it. }\end{array}$ \\
\hline 6 & $\begin{array}{l}\text { When you face the } \\
\text { difficulties of online } \\
\text { learning, what did you } \\
\text { feel? }\end{array}$ & $\begin{array}{l}\text { Most of them described that the students feel } \\
\text { sick, bored, sad, unenthusiastic, and lose the } \\
\text { passion that impacts on willingness to learn } \\
\text { English. They are confused and tired. As a } \\
\text { result, it is so complicated to comprehend the } \\
\text { EFL subject. Additionally. They feel restless, } \\
\text { frustrated, and upset, these impact the } \\
\text { students' self-worth. }\end{array}$ \\
\hline 7 & $\begin{array}{l}\text { How do you feel being an } \\
\text { EFL student during the } \\
\text { coronavirus pandemic? }\end{array}$ & $\begin{array}{l}\text { During the coronavirus pandemic (COVDI9) } \\
\text { being one of the EFL students makes them } \\
\text { feel rightfully proud although they are } \\
\text { stressed by all the things that happen they } \\
\text { can learn from it. Some of them are } \\
\text { disappointed with this pandemic situation, } \\
\text { it disturbs their learning. However, the EFL } \\
\text { students are never giving up to keep } \\
\text { struggling to conquer online learning. The } \\
\text { teaching-learning process must conduct } \\
\text { anywhere and anytime in this pandemic } \\
\text { situation although by using an online } \\
\text { learning system. } \\
\text { Few of them feel unsatisfied because they do } \\
\text { not deserve to get a high score. It burdens } \\
\text { them due to the low self-esteem of their } \\
\text { knowledge in online learning which is not } \\
\text { maximal and unenthusiastic. } \\
\text { Some of them feel that there are some } \\
\text { benefits that they can get, such as they do } \\
\text { not have to go to campus and also they can } \\
\text { learn English through online learning and } \\
\text { they can use their free time to work as a } \\
\text { private teacher. }\end{array}$ \\
\hline 8 & $\begin{array}{l}\text { what is your opinion } \\
\text { about the difficulties } \\
\text { that you face when } \\
\text { online learning? }\end{array}$ & $\begin{array}{l}\text { A variety of opinion students expresses that } \\
\text { these difficulties were experienced by every } \\
\text { student so the students should give big effort } \\
\text { and patients to understand the learning }\end{array}$ \\
\hline
\end{tabular}




\begin{tabular}{|c|c|c|}
\hline $\mathrm{NO}$ & QUESTIONS & ANSWERS \\
\hline & & $\begin{array}{l}\text { materials. } \\
\text { By using the various online method in } \\
\text { learning EFL potentially create an active } \\
\text { virtual classroom although in coronavirus } \\
\text { pandemic (COVID-19). The interaction of } \\
\text { face-to-face teaching-learning gives more } \\
\text { positive consciousness, In contrast with, } \\
\text { online learning. So, not all students } \\
\text { understand the material which is delivered } \\
\text { by using youtube or reading material. } \\
\text { The university should be more contributive } \\
\text { to assist the students in online learning. Such } \\
\text { as providing internet quota because the data } \\
\text { cellular is expensive. } \\
\text { Hopefully, this pandemic is quickly resolved } \\
\text { and can learn as usual. }\end{array}$ \\
\hline 9 & $\begin{array}{l}\text { What are the factors that } \\
\text { caused the difficulties of } \\
\text { online learning during } \\
\text { the coronavirus } \\
\text { pandemic? }\end{array}$ & $\begin{array}{l}\text { Many factors trigger the difficulties of online } \\
\text { learning, most of them facing the same } \\
\text { experiences in online learning during } \\
\text { coronavirus pandemic, such as; many young } \\
\text { children bothered me, less interaction } \\
\text { between lecturers and students, } \\
\text { unsupportive internet connection which } \\
\text { makes the lecturers explanation is not heard } \\
\text { well, lack of knowledge using high } \\
\text { technology, the students can not join the } \\
\text { real class, and they are unable to face the } \\
\text { lecturer directly, as a result, the interaction } \\
\text { between the students and the lecturers is } \\
\text { limited so the teaching-learning process is } \\
\text { not maximal. When studying at home, } \\
\text { makes the students lack concentration so } \\
\text { that they are difficult to focus on online } \\
\text { learning. }\end{array}$ \\
\hline 10 & $\begin{array}{l}\text { What are the factors that } \\
\text { caused the difficulties of } \\
\text { online learning during } \\
\text { the coronavirus } \\
\text { pandemic? }\end{array}$ & $\begin{array}{l}\text { Most of the students suggest and hope that } \\
\text { the university provides facilities for all } \\
\text { students for online learning during the } \\
\text { pandemic. } \\
\text { The lecturer should be more attentive to the }\end{array}$ \\
\hline
\end{tabular}




\begin{tabular}{|c|c|c|}
\hline $\mathrm{NO}$ & QUESTIONS & ANSWERS \\
\hline & & $\begin{array}{l}\text { EFL students, by giving the appropriate } \\
\text { tasks and assignments, also explaining the } \\
\text { learning material with understandable } \\
\text { language. } \\
\text { The teaching-learning process should be } \\
\text { blanded to reduce students' difficulties in } \\
\text { online learning because not all EFL subjects } \\
\text { can conduct in this online system. It is } \\
\text { certainly, considers as most the health } \\
\text { protocol. }\end{array}$ \\
\hline 11 & $\begin{array}{l}\text { what is the impact of } \\
\text { online learning that is } \\
\text { experienced by students } \\
\text { during the coronavirus } \\
\text { (COVID-19) pandemic? }\end{array}$ & $\begin{array}{l}\text { The students experience many impacts of } \\
\text { online learning during the coronavirus } \\
\text { pandemic, most of them face the crisis of } \\
\text { enthusiasm in learning and decreased student } \\
\text { grades. The extreme impact, Sometimes they } \\
\text { encounter excessive headaches because they } \\
\text { must look at the screen for several whole } \\
\text { hours. } \\
\text { They are lack of motivation to require } \\
\text { knowledge, they turn to get a high score, } \\
\text { without concerning the learning process, } \\
\text { they join the virtual class for attendance. } \\
\text { Laziness is more influenced by them because } \\
\text { they just stay in their comfort zone to get the } \\
\text { instant score. So indirectly, this online } \\
\text { learning teaches them to focus on the result, } \\
\text { without the effort to gain online learning. }\end{array}$ \\
\hline
\end{tabular}

2. Results of Documentation

\begin{tabular}{|l|l|l|}
\hline NO & DOCUMENTATION & \multicolumn{1}{|c|}{ EXPLANATION } \\
\hline 1 & Minutes of Meeting & $\begin{array}{l}\text { The researcher found that Screenshot Photos } \\
\text { of meeting in a virtual class by using Zoom } \\
\text { applications. }\end{array}$ \\
\hline 2 & Quiz letters & $\begin{array}{l}\text { The researcher found that the letters of } \\
\text { quizzes by using Microsoft word }\end{array}$ \\
\hline 3 & Learning virtual page & $\begin{array}{l}\text { The researcher found that the page of } \\
\text { learning online by using the link, WhatsApp } \\
\text { etc }\end{array}$ \\
\hline 4 & Assignment & The assignments found by the researchers \\
\hline
\end{tabular}




\begin{tabular}{|l|l|l|}
\hline NO & DOCUMENTATION & \multicolumn{1}{c|}{ EXPLANATION } \\
\hline & & $\begin{array}{l}\text { from some English subjects that submit via } \\
\text { online in different media such as links and } \\
\text { WhatsApp }\end{array}$ \\
\hline
\end{tabular}

\section{Discussion}

A. Difficulties faced during online learning

The difficulties are encountered by EFL students become the barriers for the students to learn online effectively, here are several difficulties that namely as follows;

a. Internet Data

The result, the researcher gained by using Google from the students stated that the internet data cellular is most consumed much money because it is used every day. According to written interview;

The student explains that the main factors are lack of Internet data packages, unbalanced internet data, running out internet data by the application when carrying out live learning, and suggestions on providing adequate funding or learning facilities as well as lecturers to simplify and summarize material so that it does not take up much internet data.

The students hope that the data cellular contribution is equal to the online learning necessity. During the online classes, many of them complain due to using internet data cellular in great quantities, such as joining Zoom meeting application, YouTube, and another online learning platform. This triggers challenges for students, especially, underprivileged students.

b. Internet Connection

Internet connection is the most crucial for the online learning process, the network is connected to the internet for online learning applications. However, internet connection is the cause of many problems. This online learning not only faces unstable internet connection for the learning process doing well but also the cause of stopped online learning activities by one side. According to the written interview;

The student: "facing difficulties when the weather suddenly becomes cloudy and the signal disappears instantly and the data runs out"

The student: "signal is lost, suddenly the power goes out in my area"

The student: "the bad network connection impact on the lecturer's explanation is unclear"

The student: "difficult to get the internet connection in a remote village" 
Unfortunately, the impact of this problem is always encountered by the students such as; they cannot understand the learning material due to the unclear voice of the lecturer or students when explaining it, difficulty to connect in virtual classroom application, also the lost network during online learning. Many factors that cause the low of internet connection such as; the remote village, the power failure, bad weather also the card of Smartphone they use. The importance of internet connection makes the students must have a Smartphone that is capable to survive a long period of learning online.

\section{c. Difficulties in Doing Assignment}

Assignment or test is used to evaluate and assess the students' knowledge, skill, and so on. If knowing a language is seen as the ability to communicate in a particular sort of situation, then the assessment will be in terms of setting up stimulation of those situations and evaluating how effective the communication is that take place (Broughton, 2003). For EFL students, communication is the main fundamental ability to assess. During online learning, it is challenging to communicate verbally. One of the problems in discussing this area of English Language Teaching is that the word to describe the activities are used in several different ways. Based on the documentation, evaluation and assessment are conducted in some ways, but during online learning, most of the students submit the assignment online. The following are some students' statements:

The student: "We as students are very difficult to do online activities, there are many obstacles during online learning".

The Student: "during the online learning, the assignments were sent by the lecturer are very large and the deadline is tight".

Most of the students argue that in this condition they must adapt themselves to do the task with the limited time, and it is complicated to do sometimes because it is hard to understand and sometimes they face the challenges to submit it because of the internet connection or technical constraints. Based on the documentation that the researcher gained from the students' quiz, it faces problems technically. There is no space on their quizzes letter which they sent to the lecturer by using word file document. This also usually occurs when the submission of the test. Moreover, the documentation shows that the students submit their tasks online by using various applications, such as WhatsApp, Edlink from SiAkad, e-mail, and so forth. 


\section{d. Intrusion}

Intrusion here is the unexpected appearance or interruption of family members, friends, and or pets that may cause disruption or diversion of online learning participants' attention during the online teaching and learning process. The students are lack concentration to interest in the lesson as a result they cannot learn well during online learning. Based on the written interview the student said that during the learning many children bothered me. Based on the written interview, the distraction comes from children who are bothering the students during the online learning which may be caused by lost focus on the learning. Learning from home cannot separate from the family member activity which is potentially become a problem for learning or amusing voice that distracts the lecturer explanation. Thus, the intrusion becomes difficult for the students to learn in the online class.

\section{e. Lack of Experience in Using Technology}

Every student who lives in the 4.0 era should have digital competence for organizing technology wisely and proficiently. One of the ability digital competence is the skill of using ICT. According to Ferrari (2012), digital competence is the set of knowledge, skills, attitudes, abilities, strategies, and awareness that are required when using ICT and digital media to perform the task, solve problems, communicate, manage information, collaborate, create and share content, and build knowledge effectively, efficiently, appropriately, critically, creatively, autonomously, flexibly, ethically, reflectively, for work, leisure, participation, learning and socializing. During online learning, the ICT is the most important skill for adapting themselves in this situation, However, based on the written interview, the student said that learners who cannot use technology would be the factors of the difficulty of online learning.

Technology is the main factor of successful online learning So that the students have to possess the skill for applying the technology nowadays become the necessity of learning. Therefore, Students who are lack of operating technology expectedly cannot study online well.

\section{B. Psychological Impact of Online Learning}

\section{a. Frustrated}

Frustrated is the feeling that students face during online learning its impacts on any aspect of human life. Frustration is an emotion that occurs in situations where a person is blocked from reaching the desired outcome. Online learning accomplices frustration which is the most pervasive emotion. The technology associates much of the frustration (Psychologist, 2021). 
Based on the written interview, the students stated that they feel restless and frustrated that it has an impact on my worth. Online learning makes the students frustrated and restless because of the load that they faced to complete the task, competing in virtual class demand. Besides, they must seek a stable internet connection which is unpredictable, it is to be worst if they live in a remote area. Additionally, internet data purchase, and possess standard technology for joining online learning. These become students' obstacles. From the written interview, The students stated that online learning decreased students' enthusiasm and decrease their scores. Other students stated that some of them felt bored and lazy. This triggers their frustration when they encounter the problem, their willingness is beyond their expectation.

b. Feeling Sadness

Online learning needs using the internet for presenting and activity in the virtual class, unfortunately, it impacts the students psycho when they face it many times, according to Dhull \& Sakshi (2021) as cited in Aurora's article, greater use of the internet is also associated with an increase in depression. Depression is a mood characterized by varying degrees of sadness, disappointment, loneliness, hopelessness, self-doubt, and guilt.

Based on the written interview, the student explained that she felt so sad and suffered losses during the learning, the material that we learned was not maximal, unpassionate, and burdened by the good score but she did not have the knowledge. Another student said that he felt sadness and emptiness. The students felt disappointed with that situation, they lose hope in online learning, also doubt themselves. They think that they are not knowledgeable about getting a good score. other students stated that she felt alike, she was sick of that but she gave herself time to take a rest and started again to chase her future dreams. Although they felt sick, sad, empty, and so forth, they overcame the struggles to take time for rest so that, they were able to charge their energy to reach their dreams.

\section{CONCLUSION}

The online learning difficulties encountered by EFL students of IAIN Langsa during the coronavirus (COVID-19) pandemic were internet data, internet connection, doing assignments, intrusion, lack of experience in using technology, comprehending the lesson of EFL, and interaction between students and lecturers. The psychological impact of the online learning difficulties encountered by EFL students of IAIN Langsa during the coronavirus (COVID-19) pandemic was frustrating and sad. 


\section{REFERENCES}

Almarabeh, T, et al. (2014). The University Of Jordan E-learning Platform; State, Students Acceptance and Challenges, Journal of Software Engineering and Application, 7, 999-1007. http://dx.doi.org/10.4236/jsea.2014.712087

Akhter, T, (2020). Problems and Challenges Faced by EFL Students of Saudi Arabia during COVID-19 Pandemic, Rupkatha Journal on Interdisciplinary Studies in Humanities, Vol. 12, No. 5, 2020. 1-7. P. 1-5. https://dx.doi.org/10.21659/rupkatha.vl2n5 .riocls23n5

Bakia, M, et al, Understanding The Implications of Online Learning For Educational Productivity, US: Department of Education, 2012.

Brown, H. D. (2001). Teaching by principles an interactive approach to language pedagogy $\left(2^{\text {nd }}\right.$ ed.). Pearson: Longman.

Bryan A., \& Volchenkova, K.N. (2016). Blended Learning: Definition, models, implications for higher education. Bulletin of the South Ural State University. Ser. Education. Educational Sciences. vol. 8, no. 2, pp. 24-30. 10.14529/ped160204

Communication, Community, and Assessment Handbook for UMass Faculty, University of Massachusetts, p. 5. retrieved 30-09-2020

Cresswell, J. W. (2003). Educational Research: Planning, conducting and evaluating quantitative and qualitative research. Thousand Oaks, CA: Sage Publication.

Ferrari, A. (2012). Digital competence in practice: An analysis of frameworks, Luxembourg: Publication of the European Union: 2012. http://www.jrc.ec.europa.eu

Frustration, Psychologist Anywhere and Anytime. Accessed 6 June 2021. https://www.psychologistanywhereanytime.com/mobile/emotional proble ms psychologist/psychologist frustration.htm

Geoffrey Broughton et, al., (2003). Teaching English as a foreign language (2nd ed.). London: Routledge.

Harmer, J. (2007). The Practice of English language teaching (4th $e d$.$) . Pearson: Longman.$

Hrastinski, S. (2008). Asynchronous and synchronous e-learning a study of asynchronous and synchronous e-learning methods discovered that each supports different purposes, Educause Quarterly, 4 (1). https://www.researchgate.net/publication/238767486 Asynchronous and Synchronous e-learning. 
Jonathan, F. (2006). Learning in real-time synchronous teaching and learning online, JossyBass.

Marsvasti, A. B. (2004). Qualitative research in sociology: An Introduction, London: Sage Publication.

Means, B, et., al, (2010). U.S. Department of Education, Office of Planning, Evaluation, and Policy Development, Evaluation of Evidence-Based Practices in Online Learning A Meta-Analysis and Review of Online Learning Studies, Washington D.C: U.S. Department of Education, 2010.

Moorhouse, B. L. (2020). Adaptations to a face-to-face initial teacher education course 'forced' online due to the COVID-19 pandemic, Journal of Education for Teaching. 10.1080/02607476.2020.1755205. https://www.researchgate.net/publication/340670666)

Setiawan, A. R., \& Ilmiyah, S. (2020). Students' worksheet for distance learning based on scientific literacy in the topic coronavirus disease 2019 (COVID-19). https://www.researchgate.net/publication/340916913.

Smart, K. L., \& Cappel, J. J. (2006). Students' Perception of Online Learning: A Comparative Study, Journal of Information Technology Education, Vol:5, 201-219 (2006) https://www.learntechlib.org/p/101752.

Smith, B. L., \& Mac Gregor, J. T. (1998). Collaborative learning: a sourcebook for higher education. University Park, PA: National Center on Postsecondary Teaching, Learning and Assessment (NCTLA).

Sudaryono, (2017). Metodologi Penelitian . Depok: PT Raja Grafindo Persada. Types of Online Learning , Fordham University (2021). https://www.fordhameduinfo/24884/online learning/7897/types of online 1 earning 